\title{
Occupational Patterns of Wildlife on a Major East Kootenay Winter-Spring Range
}

\section{R. J. HUDSON, D. M. HEBERT, AND V. C. BRINK}

Highlight: Empirical descriptions of spatial overlap of coexisting herbivores are difficult to interpret in terms of functional interaction. In an attempt to obviate some of these difficulties, partial correlation analysis was applied to the study of habitat use behavior of whitetail deer, mule deer, elk, and bighorn sheep on an important wildlife winter-spring range in southeastern British Columbia. A probe was made of the basic determinants of habital selection in order to isolate the response of represented species to the physical and vegetational environment and to summer grazing by cattle. Distinct patterns of habitat utilization were exhibited by each species. Whitetail and mule deer habitat preferences were distinguished from one another by elevation, ruggedness of terrain, and openness of forest and shrub vegetation. Elk were most widely distributed and showed the least apparent response to measured environmental parameters, whereas bighorn sheep were most localized and specific in their response to environment. Distributions of all species were only weakly influenced by the activities of grazing cattle at the level and pattern found on the study area. Partial correlation techniques appeared to offer some potential for analyzing resource division in mixed grazing systems. However, a number of technical and conceptual difficulties may limit their value in systems where reciprocal feedbacks, thresholds, and optima exist in the response of animals to environment.

Numerous studies have attempted to provide measures of competition or ecological overlap among coexisting herbivores. Generally, competition has been described in terms of the extent to which members of a multispecies assemblage graze common areas during the same season and the extent to which they utilize common forage species (Julander, 1958). These parameters, in certain situations, may adequately describe the basic elcments of competition when they are interpreted in relation to existing levels of

Authors are assistant professor, Depart ment of Animal Science, University of Alberta, Edmonton; regional wildlife biologist, Fish and Wildlife Branch, Nanaimo; and professor, Department of Plant Science, University of British Columbia, Vancouver.

The authors extend sincere appreciation to $\mathrm{Mr}$. Reginald Orich and Mr. Norman Shannon for their able assistance in the field. Research was supported jointly by the Fish and Wildlife Branch, Grazing Division of the Forest Service and Department of Agriculture of the Government of British Columbia.

Manuscript received February 17, 1975. herent in simple descriptive approaches, particularly where more subtle functional interactions exist among associated species such as have been described for the complex grazing systems of East African savannas (Bell, 1971). After all, overlapping distributions of several herbivores may be interpreted as evidence for any of a number of possible interactions ranging from mutual dependence to significant competition, since animals could be responding to the benefits of association as well as simply displaying similar habitat preferences. Similarly, nonoverlap may be an expression of active avoidance as well as ecological separation. For this reason, alternative approaches to evaluation of functional interactions should be examined.

preferred forages or directional change in range condition (Constan, 1967). However, certain difficulties are in-

In this report, an attempt to resolve some of these ambiguities is presented

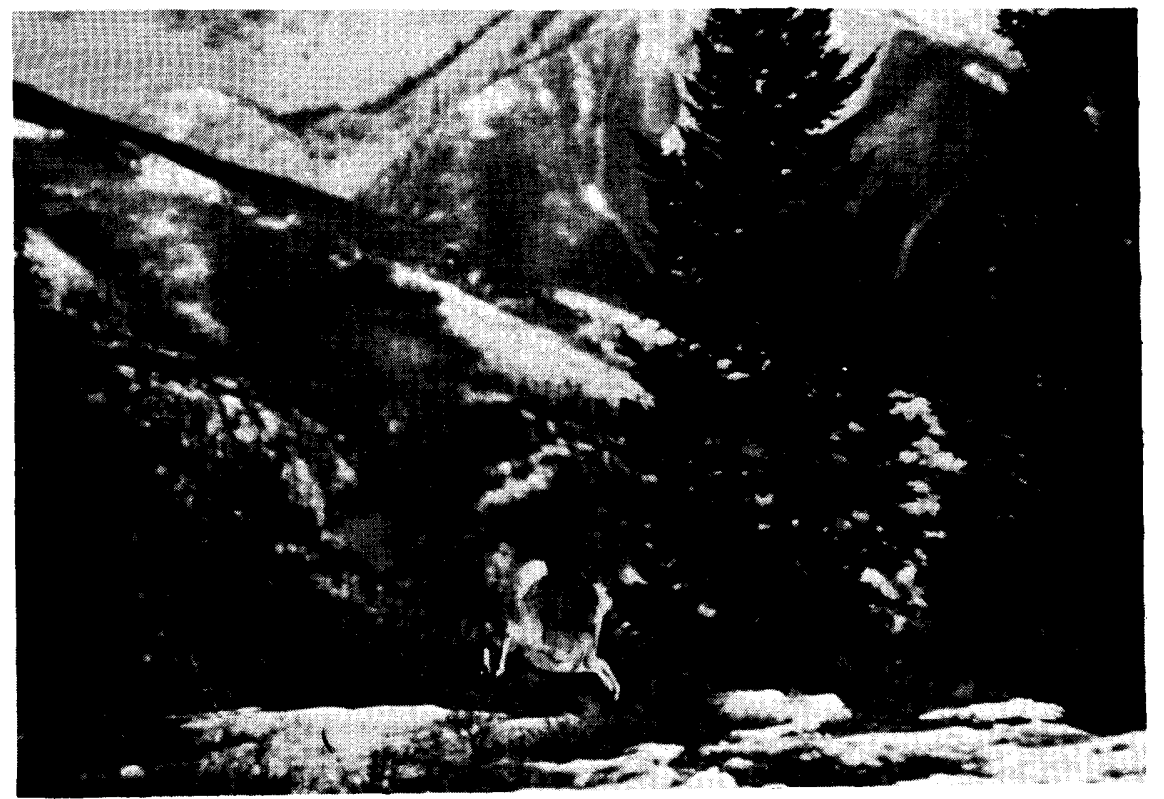

Fig. 1. Premier Rüge wildlfe winter-spring range. 
using data on the spatial relationships and habitat use behavior of whitetail deer, mulc decr, elk, and bighorn sheep coexisting with cattle on an important British Columbian range unit. The approach comprises a probe of basic determinants of habitat selection with a view to isolating the response of these species to the physical and vegetational environment and to summer grazing by cattle. The approach is basically statistical, utilizing simple and partial correlation techniques to partition observed variation in spatial abundance.

\section{Study Area}

The study was conducted on Premier Ridge, a major wildlife winter range in the Rocky Mountain Trench, southeastern British Columbia (Fig. 1). This ridge rises 1,500 feet above the floor of the Kootenay River valley adjacent to the rugged Hughes Range of the Rocky Mountains (Fig. 2).

The original plant community, now largely disturbed by logging and fire, was predominantly a mature montane forest with mixed stands of pine (Pinus ponderosa) and Douglasfir (Pseudotsuga menziesii var. glauca). Lodgepole pine (Pinus contorta var. latifolia) now occurs sporadically at all elevations usually following fire. Shrubs such as bitterbrush (Purshia tridentata), soapalallie (Shepherdia canadensis), saskatoon (Amelanchier alnifolia), and willows (Salix spp.) currently occupy large areas of bottom land and slope. Open grasslands occupy dry benches and slopes of south to west aspect where bluebunch wheatgrass (Agropyron spicatum var. inerme) and to a lesser extent, rough

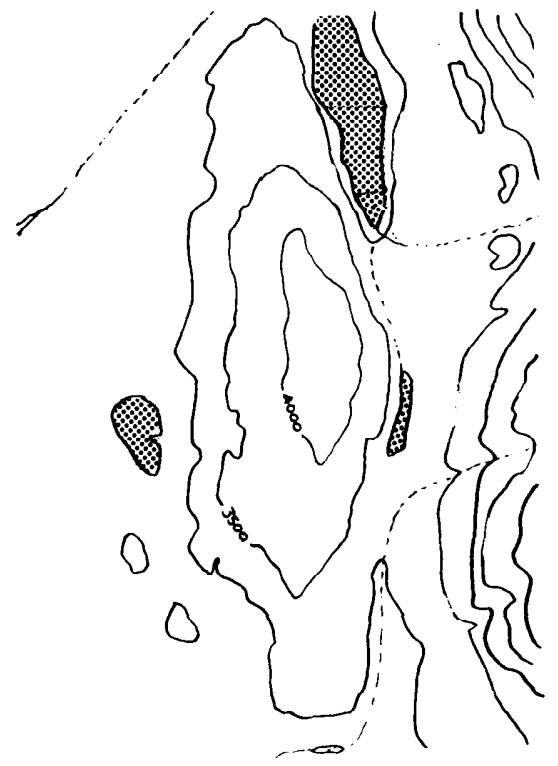

Fig. 2. Base map of the study area. fescue (Festuca scabrella) are dominant except in areas of gently topography where heavy grazing has induced succession by bluegrasses (especially Poa pratensis) and needlegrasses (Stipa columbiana and $S$. richardsonii).

Premier Ridge supports a rather complex community of native wildlife species, notably, whitetail deer (Odocoileus virginianus), mule deer (O. hemionus), elk (Cervus canadensis), and Rocky Mountain bighorn sheep (Ovis canadensis), which utilize the area from late November until late May. Current mid-winter populations are estimated to be approximately $250,250,125$, and 50 , respectively, in an area of 20 square miles. In summer between 350-500 animal unit months are allocated to cows and calves, which graze from June until October. This represents a rather important decrease in grazing pressure, since wildlife populations, particularly of elk, have declined over the past 10 years and permit-grazing of livestock has been restricted from previous levels. However, the area still must be considered heavily utilized.

\section{Methods}

For data collection and analysis, the study area was divided by a systematic grid to create 340 observational cells of $250 \mathrm{~m}$ by $250 \mathrm{~m}$ by vertical projection. Thus, the implicit assumption was that environmental characteristics measured on this scale were relevant to habitat selection by represented species. Environmental measures awarded to each cell were determined as follows:

\section{Animal Use}

Level of use by each species in each cell was assessed by direct observation obtained from travelling predetermined routes by vehicle and on foot. To correct for uneven distribution of census intensity, numbers of animals observed were expressed on a per census day basis after correction for slope-area relationships. Data on livestock use, as a determinant of wildlife distribution, was collected from June-September, 1972. Occupational patterns of whitetail, mule deer, elk, and bighorn sheep were studied from November, 1972, until May, 1973. Since environmental variables and animal distribution changed dramatically in response to spring green-up, for purposes of analysis, data were grouped into winter (NovemberMarch) and spring (March-May) periods. The numbers of animal sightings (fewer numbers of groups) pro- viding the data base of these studies were: cattle, 9,655; whitetail deer, 1,318; mule deer, 2,095; elk, 1,819; and bighorn sheep, 722 , for a total of 15,609 observations.

\section{Habitat Measurements}

Fourteen environmental parameters, in addition to the above measure of livestock use, were selected as potential determinants of spatial distribution and hence independent variables in the correlation analysis. Factors related to land form and terrain were slope, rockiness, changes in slope, elevation, aspect, snow depth, and snow cover. Factors describing vegetation were forest crown closure, shrub cover, and vegetational heterogeneity. Important forage grasses (Agropyron, Festuca, and Poa) were evaluated on the basis of biomass, leaf and culm length, percent green material, and protein content.

Measurements of basic environmental descriptors were made on a total of 270 sampling locations (cells) distributed at $250-\mathrm{m}$ intervals along 34 transects arranged to cross major plant communities. Since a relatively large number of environmental measurements from a large number of cells were required for this analysis, measurements necessarily were of ten subjective and results from one cell were freely extrapolated to adjacent cells of apparent similarity.

At each sampling location, the following measurements were made: Average slope was determined with a Sunpto level. Rockiness was awarded a subjective score of 1-10, bracketing the extremes found on the study area. Elevation at the center of each cell was estimated from topographic maps. The approximate number of changes of slope occurring within each cell $(250$ $\mathrm{m} \times 250 \mathrm{~m}$ ) served as an index of the rolling nature of terrain. Aspect was determined from compass bearings with highest values awarded to the direction of maximum insolation as suggested by Jeffery (1963). On level areas, aspect was determined by their relation to shading by adjacent ridges. Snow depth and cover were averaged from seven biweekly measurements taken at 180-225 representative locations.

Forest crown closure was estimated from aerial photographs. Heterogeneity was expressed as the number of discrete plant communities represented in the eight contiguous cells. Shrub densities were estimated subjectively and expressed as percent cover. Biomass of important forage grasses was determined by double sampling 
(Reppert et al., 1962) with subjective weight estimates calibrated with a series of 256 clips of square-meter plots. Green material was estimated as a percentage of total biomass. Protein content was determined by the Kjeldahl procedure (a large number of missing values were associated with this variable since analysis was limited to 31 samples during the winter period and 28 during spring).

\section{Graphical Display and Statistical Analysis}

Wildlife distributions were mapped, using a computer subroutine which contoured a grid from scattered data points (Coulthard and Herring, 1973). A species-association matrix, describing the relationship of numbers of animals of each species sighted, was generated from simple correlations. Use by each wildlife species in relation to measured habitat parameters and level of cattle grazing during the previous summer was analyzed by simple and partial correlation techniques (Nie et al., 1970). Simple (zero-order) coefficients were used to describe the degree to which animal use was associated with each environmental measure. However, since such coefficients are difficult to interpret when independent variables are highly correlated, partial correlation coefficients were computed while controlling first for terrain and then for vegetational characteristics. Emphasis was placed on the descriptive capabilities of correlation techniques rather than on hypothesis testing with decision statistics.

\section{Results and Discussion}

Empirical Distribution and Spatial Correspondence of Wildlife Species

Spatial distributions for winter and spring periods of whitetail deer, mule deer, elk, and bighorn sheep are mapped in Figures 3 and 4. Upon superficial inspection, distributions of the members of the assemblage appeared to be relatively discrete. Important changes in the spatial association of species accompanied spring green-up.

These relationships among species and between seasons are summarized quantitatively using a matrix of simple correlation coefficients (Table 1). During the winter period, significant spatial separation was detected for whitetail deer and mule deer, whereas significant positive association was observed between mule deer and clk.
During spring green-up the separation of whitetail deer and mule deer was maintained, while bighorn and mule deer distributions began to overlap significantly. When winter and spring distributions of each species were compared, it was found that whitetail and elk altered their distributions most markedly. Bighorn, and particularly mule deer, tended to exhibit distributions which were grossly similar to those observed in winter except that they were much less localized.

Although in this study a standard correlation technique was applied, a variety of alternative coefficients have been used to measure association of plant or animal species. For example, indices derived from information theory by Horn (1966) as applied by
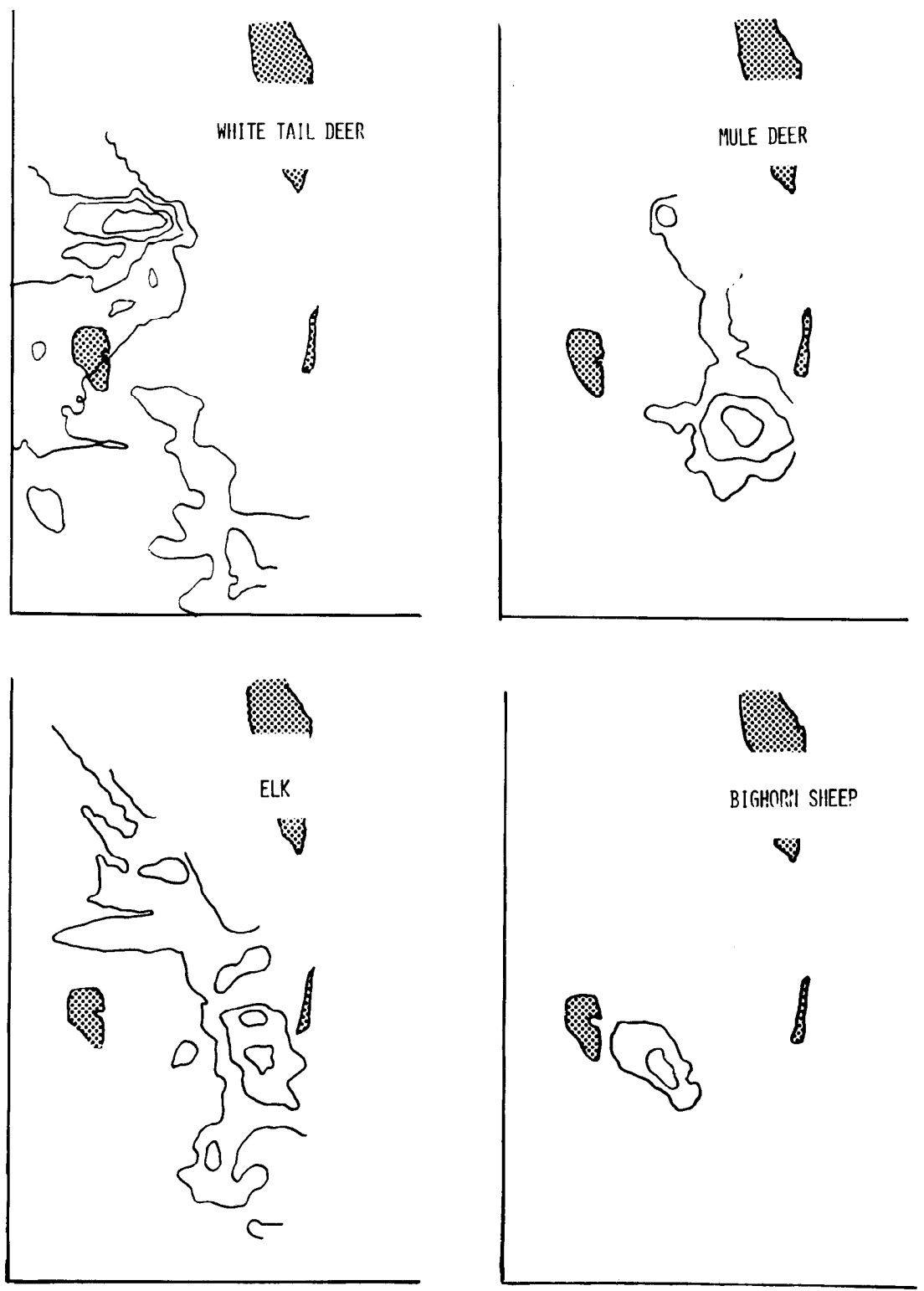

Fig. 3. Winter distribution of wildlife on the Premier Ridge study area.

Harris (1972) to East African wildlife communities could be applied to data of this type, particularly if problems of nonnormality of frequency distributions existed. However, in this study, high wildlife densities and relatively intensive census effort minimized these violations.

\section{Wildlife Distribution in Relation to Environment}

Distributions of wildlife species are of greater interest when examined in relation to features of the environment. Simple and partial correlations summarizing the responses of each species to a series of environmental factors during winter and spring periods are summarized in Tables 2 and 3, respectively. As anticipated for

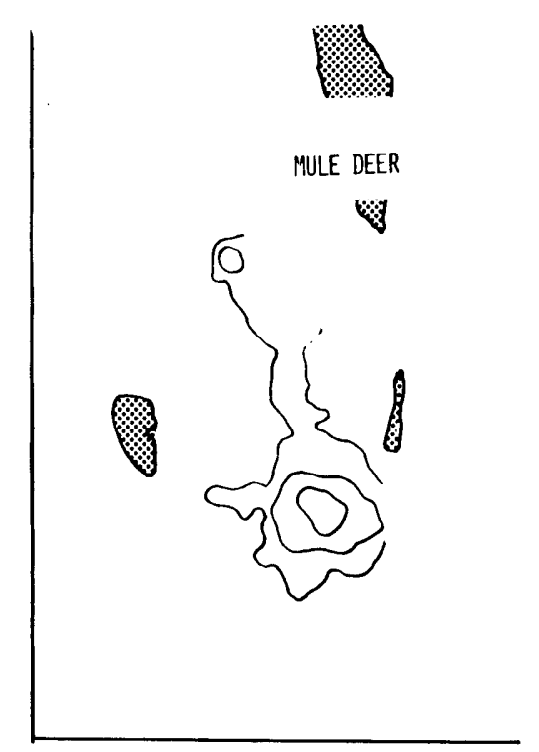




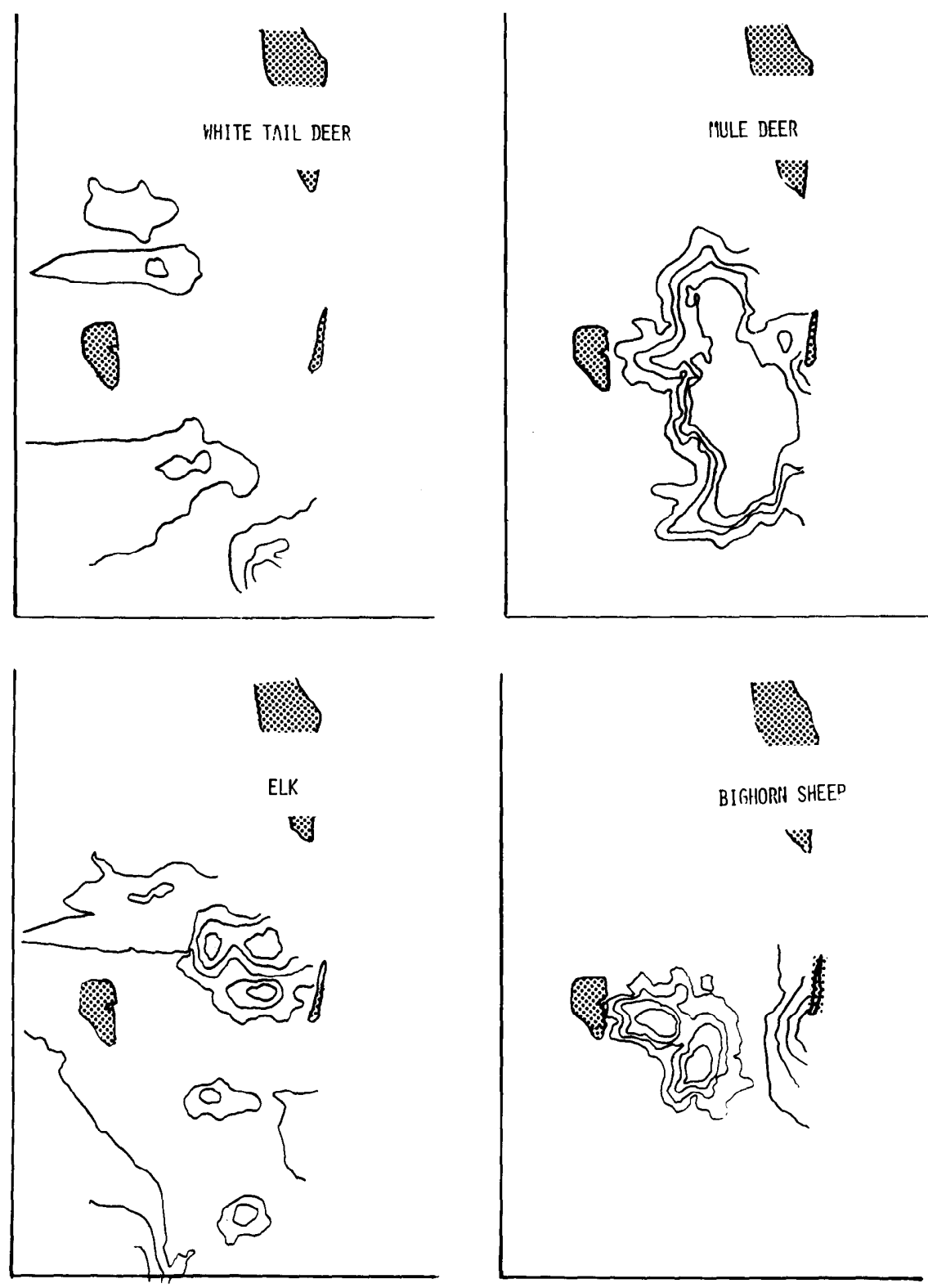

Fig. 4. Spring distribution of wildlife on the Premier Ridge study area.

animals living in complex environments, habitat selection by each species was not strongly related to any single environmental variable but rather was distributed over a number of parameters describing vegetation and terrain. Interpretation of the pattern of coefficients observed for each species within each time period follows.

During winter, whitetail deer were sighted most often at lower elevations at the base and gentle lower slopes of Premier Ridge. They were commonly found in the relatively uniform firlodgepole pine forests which supported rather higher shrub densities than found gencrally. A comparison of simple and partial coefficients suggested that their apparent negative response to slope was related more to
Their dependence on forest cover declined as they moved onto areas, many of which had been grazed the previous summer.

Mule deer utilized more rugged country at higher elcvations, where winds and insolation had cleared much of the area of snow. They were observed mainly on open shrub communities (mainly Purshia tridentata), where good stands of lightly grazed bunchgrasses existed. When the higher-order partials were examined, it appeared that their response may have been related more to vegetation than terrain, since coefficients describing their rclationship to slope and rockiness dropped from significance when vegetation effects were controlled statistically. During spring, their selection of habitat on the basis of measured habitat variables did not change dramatically.

Elk were somewhat less responsive to measured features of terrain than other species. They were most commonly sighted during winter at higher elevations, where they exhibited less sensitivity to snow cover than the two deer species or bighorn sheep. They used open forest and shrub communities with good stands of bunchgrasses, which cured with relatively high protein contents. During spring, aspect became more important as the animals sought southwesterly exposures. Their dependence on heavier stands of bunchgrasses was relaxed but since they tended to remain at higher elevations where spring growth was delayed, a negative correlation of their spatial abundance with protein content of major forage grasses was observed.

Bighorn sheep distributions were most strongly influenced by measured variables. In winter, their very strongly oriented to the southwest.

associated vegetation than slope per se. Their response during spring altered, with aspect becoming more important as they began to use areas more

Table 1. Association matrix of simple correlation coefficients describing seasonal spatial relationships of represented species. Only significant correlations $(p<.05)$ are shown.

\begin{tabular}{|c|c|c|c|c|c|c|c|c|}
\hline \multirow[b]{2}{*}{$\cdot$} & \multicolumn{4}{|c|}{ Winter } & \multicolumn{4}{|c|}{ Spring } \\
\hline & $\begin{array}{c}\text { White- } \\
\text { tail }\end{array}$ & $\begin{array}{l}\begin{array}{l}\text { Mule } \\
\text { deer }\end{array} \\
\end{array}$ & Elk & $\begin{array}{c}\begin{array}{c}\text { Bighorn } \\
\text { sheep }\end{array} \\
\end{array}$ & $\begin{array}{c}\text { White- } \\
\text { tail }\end{array}$ & $\begin{array}{l}\text { Mule } \\
\text { deer }\end{array}$ & Elk & $\begin{array}{c}\text { Bighorn } \\
\text { sheep }\end{array}$ \\
\hline \multicolumn{9}{|l|}{ Winter } \\
\hline $\begin{array}{l}\text { Whitetail } \\
\text { Mule deer }\end{array}$ & -.11 & & & & & & & \\
\hline Elk & - & .12 & & & & & & \\
\hline Bighorn sheep & - & - & - & & & & & \\
\hline \multicolumn{9}{|l|}{ Spring } \\
\hline Whitetail & - & -.10 & -.10 & - & & & & \\
\hline Mule deer & -.14 & .52 & .11 & - & -.11 & & & \\
\hline Elk & - & .13 & - & - & - & - & & \\
\hline Bighorn sheep & - & - & - & .18 & - & .20 & - & \\
\hline
\end{tabular}


Table 2. Winter wildlife distribution in relation to environmental parameters. Only significant correlation coefficients $(p \leqslant .05)$ are shown. ${ }^{1,2}$ Correlation coefficients which have lost or gained significance when partialled are in parentheses.

\begin{tabular}{|c|c|c|c|c|c|c|c|c|c|c|c|c|c|c|c|c|}
\hline \multirow[b]{2}{*}{ Species } & \multirow[b]{2}{*}{$\begin{array}{l}\text { Variables } \\
\text { controlled }\end{array}$} & \multicolumn{7}{|c|}{ Terrain } & \multicolumn{8}{|c|}{ Vegetation } \\
\hline & & Slope & $\begin{array}{c}\text { Change } \\
\text { in } \\
\text { slope }\end{array}$ & Rock & Aspect & $\begin{array}{l}\text { licva- } \\
\text { tion }\end{array}$ & $\begin{array}{r}\text { Snow } \\
\text { depth }\end{array}$ & $\begin{array}{l}\text { Snow } \\
\text { cover }\end{array}$ & $\begin{array}{c}\text { Forest } \\
\text { cover }\end{array}$ & $\begin{array}{c}\text { Shrub } \\
\text { cover }\end{array}$ & $\begin{array}{l}\text { Hetero- } \\
\text { geneity }\end{array}$ & $\begin{array}{c}\text { Forage } \\
\text { biomass }\end{array}$ & $\begin{array}{c}\text { Leaf } \\
\text { length }\end{array}$ & $\begin{array}{c}\text { Culm } \\
\text { length }\end{array}$ & $\begin{array}{c}\% \\
\text { green } \\
\end{array}$ & $\begin{array}{l}\text { Protein } \\
\text { content }\end{array}$ \\
\hline $\begin{array}{l}\text { Whitetail } \\
\text { deer }\end{array}$ & $\begin{array}{l}\text { None }^{3} \\
\text { Terrain } \\
\text { Vegetation }\end{array}$ & $\begin{array}{c}-.10 \\
C \\
(-.06)\end{array}$ & $\overline{\mathrm{C}}$ & $\begin{array}{l}\bar{C} \\
-\end{array}$ & $\begin{array}{l}- \\
\mathrm{C} \\
-\end{array}$ & $\begin{array}{r}-.18 \\
C \\
-.17\end{array}$ & $\begin{array}{l}\bar{C} \\
-\end{array}$ & $\begin{array}{l}- \\
\mathrm{C} \\
-\end{array}$ & $\begin{array}{r}.10 \\
.11 \\
C\end{array}$ & $\begin{array}{r}.10 \\
.10 \\
C\end{array}$ & $\begin{array}{r}-.15 \\
-.13 \\
\mathrm{C}\end{array}$ & $\overline{-}$ & $\begin{array}{l}- \\
\bar{C}\end{array}$ & $\begin{array}{l}- \\
\bar{C}\end{array}$ & $\begin{array}{c}(.13) \\
(.12) \\
C\end{array}$ & $\begin{array}{l}- \\
\bar{C}\end{array}$ \\
\hline Mule deer & $\begin{array}{l}\text { None } \\
\text { Terrain } \\
\text { Vegetation }\end{array}$ & $\begin{array}{c}.11 \\
C \\
(.002)\end{array}$ & $\begin{array}{c}.27 \\
\mathrm{C} \\
.24\end{array}$ & $\begin{array}{c}.10 \\
C \\
(-.03)\end{array}$ & $\begin{array}{l}- \\
\mathrm{C} \\
-\end{array}$ & $\begin{array}{r}.31 \\
\mathrm{C} \\
.25\end{array}$ & $\begin{array}{l}- \\
\mathrm{C} \\
-\end{array}$ & $\begin{array}{c}-.10 \\
C \\
(-.05)\end{array}$ & $\begin{array}{r}-.20 \\
-.16 \\
C\end{array}$ & $\begin{array}{r}.15 \\
.12 \\
\mathrm{C}\end{array}$ & $\overline{\mathrm{C}}$ & $\begin{array}{r}.23 \\
.23 \\
\mathrm{C}\end{array}$ & $\begin{array}{c}.13 \\
(.06) \\
\mathrm{C}\end{array}$ & $\begin{array}{r}.20 \\
.13 \\
\mathrm{C}\end{array}$ & $\begin{array}{c}-.17^{* *} \\
(-.10) \\
C\end{array}$ & $\begin{array}{c}(.03) \\
.13 \\
C\end{array}$ \\
\hline Elk & $\begin{array}{l}\text { None } \\
\text { Terrain } \\
\text { Vegetation }\end{array}$ & $\begin{array}{l}- \\
\mathrm{C} \\
-\end{array}$ & $\begin{array}{l}- \\
\mathrm{C} \\
-\end{array}$ & $\begin{array}{l}- \\
\mathrm{C} \\
-\end{array}$ & $\begin{array}{l}- \\
\mathrm{C} \\
-\end{array}$ & $\begin{array}{c}.38 \\
C \\
.34\end{array}$ & $\begin{array}{l}- \\
\mathrm{C} \\
-\end{array}$ & $\begin{array}{c}.16 \\
C \\
.18\end{array}$ & $\begin{array}{r}-.15 \\
.14 \\
C\end{array}$ & $\begin{array}{l}- \\
- \\
\mathrm{C}\end{array}$ & $\begin{array}{c}(.08) \\
.10 \\
C\end{array}$ & $\begin{array}{r}.18 \\
.19 \\
C\end{array}$ & $\begin{array}{r}.14 \\
.17 \\
\mathrm{C}\end{array}$ & $\begin{array}{r}.11 \\
.13 \\
C\end{array}$ & $\begin{array}{l}- \\
- \\
\mathrm{C}\end{array}$ & $\begin{array}{c}.13 \\
(.10) \\
C\end{array}$ \\
\hline $\begin{array}{l}\text { Bighorn } \\
\text { sheep }\end{array}$ & $\begin{array}{l}\text { None } \\
\text { Terrain } \\
\text { Vegetation }\end{array}$ & $\begin{array}{c}.32 \\
\mathrm{C} \\
.29\end{array}$ & $\begin{array}{r}.18 \\
\mathrm{C} \\
.17 \\
\end{array}$ & $\begin{array}{r}.43 \\
\mathrm{C} \\
.43 \\
\end{array}$ & $\begin{array}{r}.18 \\
\mathrm{C} \\
.20 \\
\end{array}$ & $\begin{array}{c}.12 \\
\mathrm{C} \\
(.06)\end{array}$ & $\overline{\mathrm{C}}$ & $\begin{array}{r}.21 \\
C \\
.20\end{array}$ & $\begin{array}{r}-.10 \\
-.10 \\
C\end{array}$ & $\begin{array}{l}- \\
- \\
\mathrm{C}\end{array}$ & $\begin{array}{r}.19 \\
.20 \\
C\end{array}$ & $\begin{array}{c}.14 \\
(.03) \\
\mathrm{C}\end{array}$ & $\begin{array}{c}.14 \\
(-.04) \\
C\end{array}$ & $\begin{array}{r}.13 \\
-.10 \\
C\end{array}$ & $\begin{array}{l}- \\
- \\
\mathrm{C}\end{array}$ & $\begin{array}{c}(.01) \\
.11 \\
C\end{array}$ \\
\hline
\end{tabular}

'Since some missing values are encountered in the data, values of $r$ at $p \leqslant .05$ differed among variahles.

${ }^{2}$ Variables denoted $C$ are controlled.

${ }^{3}$ This represents \%ero-order partials or "simple" correlation coefficients.

localized distribution was characterized by steep, relatively snow-free slopes and rugged terrain of southwest aspect. These areas, at intermediate elevation, supported moderate stands of bunchgrasses interrupted with scattered trees, shrubs, rock outcrops, and noncaespitose grasses. A positive association occurred with slope and rockiness, perhaps related to use of the area as escape terrain as well as for feeding (Geist and Petocz, 1972). When variation was partialled, an inverse relationship was evidenced with forage height. This was consistent with the observation that sheep tended to select lower bunchgrasses with fewer seedheads and more leafy material when available through winter snows. However, reciprocal cause- effect relationships between forage characteristics and habitat selection, such as exist in this case, are difficult to examine by standard correlation techniques. Spring distribution of bighorn sheep was responsive to similar habitat features except that the correlation with forage protein content increased dramatically. The reduction in association with terrain from winter to spring reflected their wider distribution during this period.

Patterns of habitat utilization exhibited by each of the coexisting species on Premier Ridge generally were similar to those reported in other montane environments. Kramer (1972) reviewed the ecological relationships of whitetail deer and mule deer and concluded that the major ecological separation of the two species in winter was on the basis of elevation, ruggedness of terrain, and openness of forest and shrub vegetation. This was confirmed in this study since mule deer showed more strongly positive correlation coefficients with elevation, slope, changes in slope, rockiness and a more negative correlation with forest cover. Reasons for these differences in habitat preference are speculative. They do not seem to be primarily related to or reinforced by interspecific behavior (Kramer, 1973). Slightly larger size and certain physiological differences may equip mule deer to cope with a slightly more exposed environment.

Elk are recognized widely to be catholic in their habitat use behavior,

Table 3. Spring wildlife distribution in relation to environmental parameters. Only significant correlation coefficients $(p \leqslant .05)$ are shown. ${ }^{1,2}$ Correlation coefficients which have lost or gained significance when partialled are in parentheses.

\begin{tabular}{|c|c|c|c|c|c|c|c|c|c|c|c|c|c|c|}
\hline \multirow[b]{2}{*}{ Species } & \multirow[b]{2}{*}{$\begin{array}{l}\text { Variables } \\
\text { controlled }\end{array}$} & \multicolumn{5}{|c|}{ Terrain } & \multicolumn{8}{|c|}{ Vegetation } \\
\hline & & Slope & $\begin{array}{c}\text { Change } \\
\text { in } \\
\text { slope }\end{array}$ & Rock & Aspect & $\begin{array}{l}\text { Eleva- } \\
\text { tion }\end{array}$ & $\begin{array}{c}\text { Forest } \\
\text { cover }\end{array}$ & $\begin{array}{c}\text { Shrub } \\
\text { cover }\end{array}$ & $\begin{array}{l}\text { Hetero- } \\
\text { geneity }\end{array}$ & $\begin{array}{l}\text { Forage } \\
\text { biomass }\end{array}$ & $\begin{array}{l}\text { Leaf } \\
\text { length }\end{array}$ & $\begin{array}{l}\text { Culm } \\
\text { length }\end{array}$ & $\begin{array}{c}\% \\
\text { green }\end{array}$ & $\begin{array}{l}\text { Protein } \\
\text { content }\end{array}$ \\
\hline $\begin{array}{l}\text { Whitetail } \\
\text { deer }\end{array}$ & $\begin{array}{l}\text { None }^{3} \\
\text { Terrain } \\
\text { Vegetation }\end{array}$ & $\begin{array}{l}-\bar{C} \\
-\end{array}$ & $\begin{array}{r}-.10 \\
\mathrm{C} \\
-\end{array}$ & $\bar{C}$ & $\begin{array}{r}.12 \\
\mathrm{C} \\
.12\end{array}$ & $\begin{array}{r}-.20 \\
C \\
-.21\end{array}$ & $\begin{array}{l}- \\
\bar{C}\end{array}$ & $\begin{array}{l}- \\
\bar{C}\end{array}$ & $\begin{array}{r}-.18 \\
-.21 \\
C\end{array}$ & $\begin{array}{l}- \\
\overline{\mathrm{C}}\end{array}$ & $\begin{array}{l}- \\
\bar{C}\end{array}$ & $\begin{array}{c}-.13 \\
(-.01) \\
C\end{array}$ & $\begin{array}{l}- \\
\bar{C}\end{array}$ & $\overline{-}$ \\
\hline Mule deer & $\begin{array}{l}\text { None } \\
\text { Terrain } \\
\text { Vegetation }\end{array}$ & $\begin{array}{l}- \\
\mathrm{C} \\
-\end{array}$ & $\begin{array}{c}.30 \\
\mathrm{C} \\
.27\end{array}$ & $\begin{array}{l}- \\
\mathrm{C} \\
-\end{array}$ & $\begin{array}{l}- \\
\text { C } \\
-\end{array}$ & $\begin{array}{c}.29 \\
\mathrm{C} \\
.23\end{array}$ & $\begin{array}{r}-.25 \\
-.19 \\
C\end{array}$ & $\begin{array}{r}.14 \\
.12 \\
\mathrm{C}\end{array}$ & $\begin{array}{c}(.11) \\
.19 \\
\mathrm{C}\end{array}$ & $\begin{array}{r}.22 \\
.22 \\
\mathrm{C}\end{array}$ & $\begin{array}{r}.19 \\
.15 \\
\mathrm{C}\end{array}$ & $\begin{array}{r}.23 \\
.19 \\
\mathrm{C}\end{array}$ & $\frac{-}{\mathrm{C}}$ & $\begin{array}{c}(-.04) \\
-.13 \\
C\end{array}$ \\
\hline Elk & $\begin{array}{l}\text { None } \\
\text { Tcrrain } \\
\text { Vegetation }\end{array}$ & $\begin{array}{l}- \\
\text { C } \\
-\end{array}$ & $\begin{array}{l}- \\
\text { C } \\
-\end{array}$ & $\begin{array}{l}- \\
\mathrm{C} \\
-\end{array}$ & $\begin{array}{c}.18 \\
\mathrm{C} \\
.16\end{array}$ & $\begin{array}{c}.34 \\
\mathrm{C} \\
.33\end{array}$ & $\overline{-}$ & $\frac{-}{\mathrm{C}}$ & $\begin{array}{l}- \\
\bar{C}\end{array}$ & $\frac{-}{\mathrm{C}}$ & $\overline{-}$ & $\begin{array}{l}- \\
\bar{C}\end{array}$ & $\overline{-}$ & $\begin{array}{r}-.16 \\
-.22 \\
C\end{array}$ \\
\hline $\begin{array}{c}\text { Bighorn } \\
\text { sheep }\end{array}$ & $\begin{array}{l}\text { None } \\
\text { Terrain } \\
\text { Vegetation }\end{array}$ & $\begin{array}{c}.18 \\
\mathrm{C} \\
.17\end{array}$ & $\begin{array}{c}.10 \\
\mathrm{C} \\
(.08)\end{array}$ & $\begin{array}{c}.23 \\
\mathrm{C} \\
.23\end{array}$ & $\begin{array}{l}- \\
-\end{array}$ & $\begin{array}{r}.10 \\
\mathrm{C} \\
.12\end{array}$ & $\begin{array}{r}-.11 \\
-.12 \\
C\end{array}$ & $\frac{-}{\mathrm{C}}$ & $\begin{array}{r}.20 \\
.22 \\
\mathrm{C}\end{array}$ & $\begin{array}{l}- \\
- \\
C\end{array}$ & $\frac{-}{c}$ & $\begin{array}{l}- \\
\bar{C}\end{array}$ & $\overline{-}$ & $\begin{array}{r}.44 \\
.42 \\
\mathrm{C}\end{array}$ \\
\hline
\end{tabular}

\footnotetext{
${ }^{1}$ Since some missing values were encountered in the data, values of $r$ at $p \leqslant .05$ differed among variables.

${ }^{2}$ Variables denoted $C$ are controlled.

${ }^{3}$ This represented zero-order partials or "simple" correlation coefficients.
} 
adapting successfully to a wide variety of environments. On Premier Ridge, this species was widely distributed and was able to exploit areas not effectively utilized by coexisting species, particularly those at higher elevation and with more complete snow cover.

Bighorn shecp on the study area, as in many areas (Constan, 1972) tended to utilize small rather specific areas preferentially, ignoring what appeared superficially to be available habitat. Partially for this reason, the bighorn has been envisaged as a species locked into stereotyped range use by tradition. However, this is a characteristic shared by domestic sheep and when the response of the animal to range structure (Arnold, 1964) and forage quality (Hebert, 1973) is considered, the adaptiveness is more easily appreciated.

\section{Wildlife Distribution in Relation to Livestock Grazing}

Both positive and negative responses of wild herbivores to areas grazed by cattle have been observed (Hedrick, 1968; Skovlin et al., 1968). On Prcmicr Ridge, under the prevailing system of management, activities of grazing cattle during the previous summer were not significantly associated with wildlife distribution, neither when their effects were considered directly nor as mediated through changes in vegetation. The general weakness of the observed response may be of several origins. When the entire study area was considered, livestock grazing accounted for a relatively small part of total variation observed in forage biomass, and leaf and culm lengths (zero-order values were $-.12,0.17,-.17$, respectively). Forest crown closure held a stronger relationship with forage biomass $(r=-.20)$. Although under this grazing rcgimen, damage to plant communities was severe in certain parts of the study area, particularly near water or salt, it was localized creating a relatively complex interspersion of more and less heavily grazed areas. Often this pattern was more finely grained than the sampling grid chosen in this study. Clearer patterns likely would emerge in less heterogeneous habitats where livestock use was more uniform.

\section{Conclusions}

Partial correlation techniques appeared to be useful for quantifying habitat use behaviour and for resolving some of the ambiguities of overlapping habitat preferences exhibited by members of mixed grazing systems. The approach was applied to the study of resource division within a wildlife community comprised of whitetail deer, mule deer, elk, and bighorn shecp, and between each of these species and domestic livestock. However, a number of technical and conceptual limitations were recognized. The techniques are designed for continuous characteristics rather than presence or absence measurements which may be important in many grazing systems. They are based on an assumption of linear relationships between animal use and habitat characteristics, whereas thresholds and optima appear to predominate in natural systems. Although a variety of transformations can be applied to achieve linearity, their choice is often arbitrary and may become cumbersome where large numbers of independent variables are involved. Finally, it is not clear that grazing animals perceive their environment as a series of divisible attributes. Habitat selection may be based on complex search-images which are comprised of unique combinations of habital features (Klopfer, 1970). Although animals do exhibit preferential use of discrete areas, factors defining these preferences are poorly understood.

\section{Literature Cited}

Arnold, G. W. 1964. Factors within plant association affecting the behavior and performance of grazing animals. In: D. J. Crisp, ed. Grazing in terrestrial and marine environments. Blackwell Sci. Publ., Oxford. 33-154.

Bell, R. H. V. 1971. A grazing ecosystem in the Serengeti. Sci. Amer. 225:86-93.

Constan, K. J. 1967. Food habits, range use and relationships of bighorn sheep to mule deer and elk in winter, Gallatin Canyon, Montana. MS Thesis, Montana State Univ. 43 p.

Constan, K. J. 1972. Winter food and range use of three species of ungulates. $\mathbf{J}$. Wildl. Manage. 36:1068-1076.

Coulthard, W. J., and W. M. Herring. 1973. Contouring a set of scattered data points. Mimeo. Computing Center, Univ. of British Columbia. $4 \mathrm{p}$.

Geist, V., and R. G. Petocz. 1972. On the temporal and spatial occupation patterns of a wintering area by bighorn sheep and their theoretical implications. Canadian Wildlife Service files, Edmonton, $36 \mathrm{p}$. Mimeo.

Harris, L D. 1972. An ecological description of a semi-arid East African ecosystem. Range Sci. Dep., Colorado State Univ. Sci. Series 11.80 p.

Herbert, D. M. 1973. Altitudinal migration as a factor in the nutrition of bighorn sheep. PhD Thesis, Univ. of British Columbia. $355 \mathrm{p}$.

Hedrick, D. W. 1968. Livestock grazing and game management. In: H. C. Black, ed. Wildlife and reforestation in the Pacific Northwest. Oregon State Univ., Corvallis.

Horn, H. S. 1966. Measurement of "overlap" in comparative ecological studies. Amer. Natur. 100:419-424.

Jeffery, D. E. 1963. Factors influencing elk and cattle distribution on Willow Creek Summer Range, Utah. MS Thesis. Utah State Univ. 46 p.

Julander, O. 1958. Techniques in studying competition between big game and livestock. J. Range Manage. 11:18-21.

Kramer, A. 1972. A review of ecological relationships between mule and whitetailed deer. Alberta Dep. Lands and Forests, Wildl. Tech. Bull. No. 3.

Kramer, A. 1973. Interspecific behavior and dispersion of two sympatric deer species. J. Wildl. Ma nage. 37:288-300.

Nie, N. H., D. H. Bent, and C. Hadlai Hull. 1970. SPSS: Statistical package for the social sciences. McGraw-Hill, New York.

Reppert, J. N., R. H. Hughes, and D. A. Duncan. 1963. Herbage yield and its correlation with other plant measurements. In: Range research methods. U.S. Dep. Agr. Misc. Pub. 940. p. 15-21.

Skovlin, J. M., P. J. Edgerton, and R. W. Harris. 1968. The influence of cattle management on deer and elk. Trans. N. Amer. Nat. Res. Conf. 33:169-181.

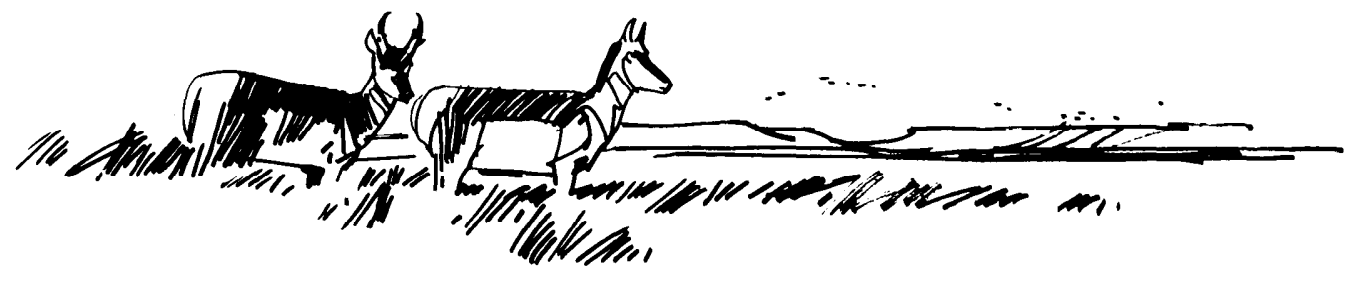

